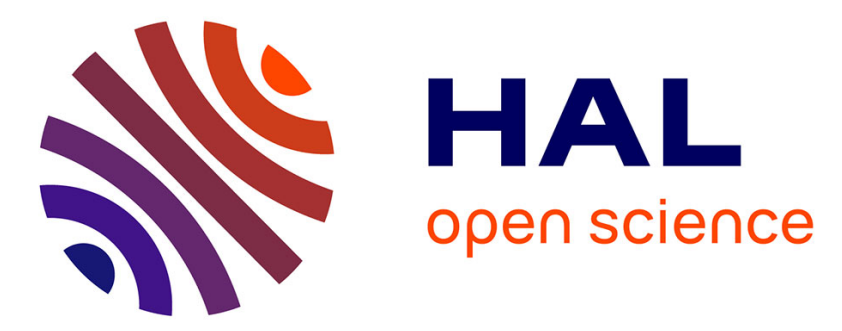

\title{
Functions of serotonin in hypoxic pulmonary vascular remodeling.
}

Juan M Esteve, Jean-Marie Launay, Odile Kellermann, Luc Maroteaux

\section{To cite this version:}

Juan M Esteve, Jean-Marie Launay, Odile Kellermann, Luc Maroteaux. Functions of serotonin in hypoxic pulmonary vascular remodeling.. Cell Biochemistry and Biophysics, 2006, 47 (1), pp.33-44. 10.1385/CBB:47:1:33 . hal-01274919

\section{HAL Id: hal-01274919 https://hal.science/hal-01274919}

Submitted on 17 Feb 2016

HAL is a multi-disciplinary open access archive for the deposit and dissemination of scientific research documents, whether they are published or not. The documents may come from teaching and research institutions in France or abroad, or from public or private research centers.
L'archive ouverte pluridisciplinaire $\mathbf{H A L}$, est destinée au dépôt et à la diffusion de documents scientifiques de niveau recherche, publiés ou non, émanant des établissements d'enseignement et de recherche français ou étrangers, des laboratoires publics ou privés. 
FUNCTIONS OF SEROTONIN IN HYPOXIC PULMONARY VASCULAR REMODELING

Esteve Juan $\mathbf{M}^{1}$, Launay Jean-Marie ${ }^{3}$, Kellermann Odile ${ }^{2}$, Maroteaux Luc ${ }^{1,4}$

Short title: Serotonin and hypoxic lung

${ }^{1}$ IGBMC, F-67400 France ; INSERM, U596, Illkirch, F-67400 France ; CNRS UMR7104, Illkirch, F-67400 France ; Univ Strasbourg, Illkirch, F-67400 France.

${ }^{2}$ CNRS, UPR1983, Villejuif, F-94805 France

${ }^{3}$ Service de Biochimie, Hôpital Lariboisière, AP-HP, Paris, F-75010 France ; IFR139, EA3621, Paris, F-75010 France.

${ }^{4}$ INSERM, U616, Paris, F-75013 France ; Hop Pitié-Salpetrière, Paris, F-75013 France ; Univ Pierre et Marie Curie, Paris, F-75013 France.

Author for correspondence: Luc Maroteaux INSERM, U616; Hopital Pitié-Salpetrière; Université Pierre et Marie Curie Paris; Bat Pédiatrie, 47 Bd de l'Hopital 75013 Paris, France. TEL: (33) 0142 $162673 \quad$ FAX: (33) $0145709990 \quad$ Email: luc.maroteaux@chups.jussieu.fr

total word count: 7410, references: 96, figures: 3 


\section{Abstract}

In lung vasculature, reversible constriction of smooth muscle cells exists in response to acute decrease in oxygen levels (hypoxia). Progressive and irreversible structural remodeling that reduces blood vessel lumen takes place in response to chronic hypoxia and results in pulmonary hypertension. Several studies have shown a role of serotonin in regulating acute and chronic hypoxic responses. In this review the contribution of serotonin, its receptors and transporter in lung hypoxic responses is discussed. Hypoxic conditions modify plasma levels of serotonin, serotonin transporter activity, and expression of $5-\mathrm{HT}_{1 \mathrm{~B}}$ and $5-\mathrm{HT}_{2 \mathrm{~B}}$ receptors. These appear required for pulmonary vascular cell proliferation, which depends on the ratio between reactive oxygen species and nitric oxide. A heterozygous mutation was identified in the $5-\mathrm{HT}_{2 \mathrm{~B}}$ receptor gene of a patient who developed pulmonary hypertension after fenfluramines anorexigen treatment. This C-terminus truncated 5- $\mathrm{HT}_{2 \mathrm{~B}}$ mutant receptor presents lower nitric oxide coupling, and higher cell proliferation capacity than wildtype receptor. Under low oxygen tension, cells increase the transcription of specific genes via stabilization of the transcription factor HIF-1. Factors such as angiotensin II or thrombin that can also control HIF-1 pathway, contribute to pulmonary vascular remodeling. The 5$\mathrm{HT}_{2 \mathrm{~B}}$ receptor via phosphatidylinositol-3 kinase/Akt activates NF-kappaB, which is involved in the regulation of HIF-1 expression. A control of HIF-1 by 5-HT $2 \mathrm{~B}$ receptors explains why expression of pulmonary vascular remodeling factors, such as endothelin-1 or TGF-beta, which is HIF-1-alpha regulated, is not modified in hypoxic 5- $\mathrm{HT}_{2 \mathrm{~B}}$ receptor mutant mice. Understanding the detailed mechanisms involved in lung hypoxic responses may provide general insight into pulmonary hypertension pathogenesis.

Keywords: Arteries; Cell Division; Dexfenfluramine; Hypoxia; Physiopathology; Pulmonary Hypertension; Receptor; Serotonin; Transporter; Vascular Remodeling. 


\section{Acknowledgements}

We wish to acknowledge Dr V. Setola for critical reading of the manuscript.

This work has been supported by funds from the Centre National de la Recherche Scientifique, the

Institut National de la Santé et de la Recherche Médicale, the Université Louis Pasteur (Strasbourg) and Pierre et Marie Curie (Paris VI), and by grants from the Fondation pour la Recherche Médicale, the Fondation de France, the Association pour la Recherche contre le Cancer and the French ministry of research. 


\section{Introduction}

Aerobic evolution has resulted in mammalian cells and tissues metabolism that is oxygendependent. At normal $\mathrm{O}_{2}$ tension, oxidative phosphorylation is the principal energy supply for eukaryotic cells but at low $\mathrm{O}_{2}$ tension, metabolic switches turn off mitochondrial electron transport and activate anaerobic glycolysis. Maintenance of normal tissue function thus depends on a continuous supply of $\mathrm{O}_{2}$, so it is crucial that the body detects and responds rapidly to hypoxia (1). The vascular system responds to acute hypoxia in several ways. In the systemic arterial system, acute hypoxia causes vasodilatation; in pulmonary arteries, however, it elicits reversible vasoconstriction (2). Unlike acute hypoxia, in response to chronic hypoxia, pulmonary vasculature remodeling (PVR) takes place upon persistent vasoconstriction, resulting in reduced blood vessel lumen diameter, increased resistance. This persistent vasoconstriction, when permanent becomes irreversible and causes pulmonary hypertension (PH) (3). PVR results from alterations of the balance between the effects of vasodilators and antiproliferative agents produced by the endothelium (e.g., prostacyclin and nitric oxide (NO·), and vasoconstrictors and mitogenic factors (e.g., endothelin-1, endothelium-derived growth factor, and 5-HT) (4-6). Understanding the mechanisms underlying irreversible PVR is an important step in defining therapeutic targets, since many known pulmonary vasodilators diminish pulmonary remodeling by reducing pulmonary pressure $(7,8)$, and remodeling of the walls of distal pulmonary arteries is common in secondary and primary $\mathrm{PH}(9)$.

Serotonin (5-hydroxytryptamine, 5-HT) mediates myriad functions in the nervous and vascular systems. In the central nervous system, 5-HT is synthesized by neurons in the raphe nucleus; in the periphery, 5-HT is produced by the enterochromaffin cells of the gut. The actions of 5-HT are mediated by four receptor classes: ligand-gated cation channels ( 5 - $\mathrm{HT}_{3}$ receptors $)$ and three groups of $\mathrm{G}$ protein-coupled receptors $\left(5-\mathrm{HT}_{1 / 5}, 5-\mathrm{HT}_{2}, 5-\mathrm{HT}_{4 / 6 / 7}\right)$, each of which exhibits coupling to different in $\mathrm{G}$ proteins (10). The $5-\mathrm{HT}_{1 / 5}$ receptor $\left(5-\mathrm{HT}_{1} \mathrm{R}\right)$ subfamily has 7 members $\left(5-\mathrm{HT}_{1 \mathrm{~A}}, 5-\mathrm{HT}_{1 \mathrm{~B}}, 5-\mathrm{HT}_{1 \mathrm{D}}, 5-\mathrm{HT}_{1 \mathrm{E}}, 5-\mathrm{HT}_{1 \mathrm{~F}}, 5-\mathrm{ht}_{5 \mathrm{~A}}\right.$, and 5-ht $\left.{ }_{5 \mathrm{~B}}\right)$ that are negatively coupled to adenylyl 
cyclase via pertussis toxin-sensitive $\mathrm{G}_{\mathrm{i} / \mathrm{o}}$ proteins, leading to decreases in intracellular cAMP. The 5$\mathrm{HT}_{2} \mathrm{R}$ subfamily comprises 3 members $\left(5-\mathrm{HT}_{2 \mathrm{~A}}, 5-\mathrm{HT}_{2 \mathrm{~B}}\right.$, and $\left.5-\mathrm{HT}_{2 \mathrm{C}}\right)$ that are positively coupled to phospholipase $C(P L C)$ via $G_{q / 11}$ proteins, leading to increases in intracellular inositol 1,4,5trisphosphate $\left(\mathrm{IP}_{3}\right)$, 1,2-diacylglycerol (DAG) and $\mathrm{Ca}^{2+}$. The 5- $\mathrm{HT}_{4}, 5-\mathrm{HT}_{6}$, and 5-HT 7 Rs are positively coupled to adenylyl cyclase via cholera toxin-sensitive $\mathrm{G}_{\mathrm{s}}$ proteins, leading to increases in intracellular cAMP.

Several studies have demonstrated a role for 5-HTRs in regulating hypoxic responses. For instance, in the pond snail Helisoma trivolvis, a decrease in environmental $\mathrm{O}_{2}$ levels after gastrulation stimulates cilia-mediated rotational movements of the embryo; this hypoxia-induced response is mediated by two serotonergic sensory-motor neurons that both detect reduced $\mathrm{O}_{2}$ levels and activate ciliary movements (11). Also, intermittent hypoxia causes a long-term facilitation (LTF) of respiratory motor output; this neural plasticity requires $5-\mathrm{HT}_{1 \mathrm{~A}}, 5-\mathrm{HT}_{1 \mathrm{~B}}$, and $5-\mathrm{HT}_{2} \mathrm{Rs}(12)$. Furthermore, chronic hypoxia enhances LTF-evoked responses to intermittent hypoxia; this metaplasticity is mediated by $5-\mathrm{HT}_{2}$ and $5-\mathrm{HT}_{6}$ and/or 5- $\mathrm{HT}_{7} \mathrm{Rs}$ (13). Different chemosensory organs such as the carotid bodies (CB) and pulmonary neuroepithelial bodies (NEB) respond to hypoxia in a serotonin-dependent fashion. CB type I cells contain 5-HT and express 5-HT 1 , $5-\mathrm{HT}_{3}$, and 5-HT ${ }_{5 \mathrm{~A}}$ Rs that affect $\mathrm{CB}$ function when arterial $\mathrm{pO}_{2}$ is reduced (14). NEBs release 5-HT in response to acute hypoxia by a mechanism involving the 5-HT ${ }_{3} \mathrm{R}(15)$. Unlike hypoxic responses in the nervous system, which involve many different 5-HTR subtypes, hypoxia-induced vasoconstriction in the pulmonary vasculature appears to involve only $5-\mathrm{HT}_{1}$ and $5-\mathrm{HT}_{2} \mathrm{Rs}$. In recent years, several studies have demonstrated that 5-HTRs control hypoxic responses in the pulmonary vascular system (16). The exact pathways through which hypoxia causes vasoconstriction and pulmonary vascular remodeling (PVR) are just beginning to be identified. What is clear, however, is that hypoxia alters molecular (e.g., protein expression) and cellular (e.g., proliferation) processes via mechanisms that involve serotonin, its receptors, and its transporter to elicit the physiological, pulmonary responses to hypoxia (vasoconstriction and PVR). In this 
review, we will highlight the current understanding of the serotonin-dependent mechanisms underlying pulmonary hypoxic responses.

\section{Regulation by 5-HT of hypoxia-induced PVR}

\subsection{Hypoxic conditions modify 5-HT levels}

The function of 5-HTRs in hypoxic responses in the pulmonary vasculature must be dependent on the presence of suitable 5-HT levels activating these receptors. In healthy subjects, unconjugated plasma 5-HT levels are low $(<10 \mathrm{nM})$; however, in PH patients, plasma 5-HT is consistently elevated (17-19). A deficiency in platelet 5-HT storage, as is characteristic of Fawn hooded rats, contributes to the development of severe PH under both normoxic (20) and hypoxic (high altitude) (21) conditions. These observations suggest an etiological role for 5-HT in the development of $\mathrm{PH}$ and raise two important questions: 1) what is the source of 5-HT in the pulmonary vasculature, and 2) how does reduced $\mathrm{O}_{2}$ lead to an increase in plasma 5-HT levels?

In the periphery, 5-HT is synthesized and secreted from neuroendocrine enterochromaffin cells in the gut. 5-HT is mainly eliminated by uptake in lung endothelial cells, where it is then degraded by MAO (22). Platelets take up 5-HT through the 5-HT transporter (5-HTT) and storebut only slowly degrade - the monoamine. Former studies have shown that long-term hypoxia causes decreased platelet counts and short-term hypoxia increased platelet counts (23). Later, it has been established that chronic hypoxia, a stimulator of erythropoiesis, causes thrombocytopenia in laboratory animals. The thrombocytopenia is most likely the result of a reduction in the production of platelets caused by a decrease in the number of megakaryocytes in the bone marrow. The thrombocytopenia seems to be caused by competition of a precursor cell of the erythrocytic and megakaryocytic cell lines (24). Moreover, hypoxia facilitates platelets aggregation (25). Alteration of platelet number and/or function under hypoxic conditions could thus concertedly reduce 5-HT uptake and would explain hypoxia-induced increases in circulating plasma 5-HT. In this regard, platelet activation was found in the pulmonary vessels of patients with $\mathrm{PH}$ secondary to chronic 
obstructive pulmonary disease (26), and platelet survival time is reduced in patients with hypoxemia and $\mathrm{PH}$ (27). Anti-platelet agents, such as dipyridamole, reduce hypoxemic $\mathrm{PH}$ and the thickness of pulmonary arteries in response to chronic hypoxia (28). Based on these results, it has been postulated that circulating plasma 5-HT may originate from platelets (29).

Pulmonary NEB also secrete 5-HT in response to airway hypoxia (15). In this way, cellular and molecular hypoxia-regulated mechanisms, which have an effect on circulating plasma 5-HT levels, probably involve platelets and pulmonary NEB, as well as reductions in the lungs' ability to uptake and/or remove 5-HT. The 5- $\mathrm{HT}_{2 \mathrm{~A}} \mathrm{Rs}$ have been detected in platelets $(30,31)$, where they enhance platelets aggregation (25). The activation of presynaptic $5-\mathrm{HT}_{1 \mathrm{~B} / \mathrm{D}} \mathrm{R}$ decreases $5-\mathrm{HT}$ release (32), and in neonatal rabbit pulmonary NEB, 5-HT 3 Rs are involved in a positive feedback loop resulting in hypoxia-induced 5-HT release (15). Together these observations suggest that 5-HT receptors control plasma levels of their ligand in response to hypoxia.

\subsection{Putative role of 5-HTT in the hypoxic PVR}

In recent years, many studies have explored the possible role of 5-HTT in hypoxia-induced PVR. Hypoxia causes changes in 5-HTT expression: acute and chronic hypoxia increase 5-HTT mRNA levels in rat pulmonary arteries (33). Upon acute hypoxia, specific 5-HT transport is increased in porcine pulmonary artery endothelial cells without a concomitant increase in $K_{\mathrm{m}}$; Acute hypoxia (i) results in an elevation of the maximal uptake rate $\left(V_{\max }\right)$, implying de novo protein synthesis, and (ii) modifies plasma membrane phospholipids and consequently its fluidity (34). Conversely, chronic hypoxia reduces 5-HT uptake by pulmonary arteries (35).

In rat pulmonary artery SMC, 5-HT induces DNA synthesis, and acute hypoxia potentiates this mitogenic effect. The increase in DNA synthesis can be prevented by high concentrations of 5HTT inhibitors (36). In mice, increased PVR as a result of exposure to chronic hypoxia is partially reduced by the 5-HTT inhibitors citalopram and fluoxetine (37). Nonetheless, in sodium-free conditions (i.e., without 5-HT uptake), 5-HTT inhibitors still attenuated 5-HT-induced mitogenesis (38). Importantly, some 5-HTT inhibitors (including citalopram and fluoxetine) have $\mu \mathrm{M}$ affinities 
for $5-\mathrm{HT}_{2} \mathrm{R}$ (39). Recent results indicate that there is synergy between the inhibitory effects of 5$\mathrm{HT}_{1 \mathrm{~B}} \mathrm{R}$ antagonists and 5-HTT inhibitors on 5-HT-induced pulmonary vasoconstriction (40) and that nordexfenfluramine (NorDF)-induced vasoconstriction is not dependent on 5-HTT-mediated release of endogenous 5-HT but rather via direct activation of 5-HTRs (41). These observations suggest that 5-HT uptake by 5-HTT cannot fully account for the proliferative action of 5-HT, and support a role for 5-HTRs. The proposition that the long 5-HTT promoter polymorphism promotes PVR through increased 5-HTT expression does not fully explain why patients who develop PH after dexfenfluramine (DF) treatment have the same proportion of this polymorphism as do $\mathrm{PH}$ patients in general (42) (Launay unpublished). Moreover, the report that PVR after chronic hypoxia is reduced - but not completely abolished-in mice deficient for 5-HTT gene (43) demonstrates that 5-HTT does not solely mediate hypoxia-induced PVR.

\subsection{Regulation of hypoxia-induced PVR by 5-HTRs}

Different mechanical factors have been shown to induce PVR. Chronic hypoxia can stimulate PVR directly and/or by a persistent vasoconstriction process as already suggested (44). Despite sustained hypoxia, vasoconstriction persists but subsides somewhat as PVR progresses (7). Neurohumoral factors such as 5-HT/5-HTRs may be implicated.

The 5-HT ${ }_{1 \mathrm{~B}} \mathrm{R}$-mediated contractile response to 5-HT or 5-carboxamidotryptamine is increased in pulmonary arteries isolated from chronic hypoxic wild-type mice. However, the activity of 5-HT $\mathrm{HB}_{1 \mathrm{~B}} \mathrm{R}$ does not seem to be limiting, as 5-HT $\mathrm{H}_{1 \mathrm{~B}} \mathrm{R}$ knockout mice still respond to hypoxia but develop less severe PH and PVR than do wild-type mice (45). Discordantly, Marcos et al. report that chronic hypoxia $\left(10 \% \mathrm{O}_{2}\right.$ for 2 weeks)-induced pulmonary hypertension and increased vessel muscularization were not reduced by the 5- $\mathrm{HT}_{1 \mathrm{~B} / \mathrm{DD}} \mathrm{R}$ antagonist GR127935 (37). Thus, the role of 5-HT1BR in hypoxia-induced PH and PVR remains unclear and may be speciesor strain-sensitive.

In ovine common carotid arteries, despite altering the contractile response, acute hypoxia had no effect on $5-\mathrm{HT}_{2 \mathrm{~A}} \mathrm{R}$ coupling to $\mathrm{IP}_{3}$ second-messenger production (46). Similarly, acute 
hypoxia reduced 5-HTR density and agonist affinity in adult bovine common carotid arteries (47).

However, the role of 5- $\mathrm{HT}_{2 \mathrm{~A}} \mathrm{R}$ in hypoxia-induced PH and PVR is not clear, since the receptor's expression is not modified in the lung vasculature of mice exposed to $10 \% \mathrm{O}_{2}$ for 5 weeks (48). Furthermore, in mice, the effects of chronic hypoxia on pulmonary artery pressure and vessel muscularization are insensitive to the $5-\mathrm{HT}_{2 \mathrm{~A}} \mathrm{R}$ antagonist ketanserin (37).

Interestingly, mice with pharmacologically or genetically inactive $5-\mathrm{HT}_{2 \mathrm{~B}} \mathrm{R}$ do not develop $\mathrm{PH}$ and PVR following chronic hypoxia, even though the acute hypoxic response (vasoconstriction) is intact (48). Therefore, the $5-\mathrm{HT}_{2 \mathrm{~B}} \mathrm{R}$ is a key factor in the molecular signaling pathways that couple chronic hypoxia to PH and PVR, a pathway independent of acute hypoxia-induced vasoconstriction. The 5- $\mathrm{HT}_{2 \mathrm{~B}} \mathrm{R}$ also functionally interacts with the 5- $\mathrm{HT}_{1 \mathrm{~B}} \mathrm{R}$ and the 5-HTT, whose roles in PH and PVR are rather well established. For instance, 5-HT ${ }_{1 \mathrm{~B}} \mathrm{R}$ and 5-HTT activities are modulated by $5-\mathrm{HT}_{2 \mathrm{~B}} \mathrm{Rs}(29,49)$. Similarly, MacLean proposed a functional interaction between $\mathrm{G}_{\mathrm{i}^{-}}$ coupled $\left(5-\mathrm{HT}_{1 \mathrm{~B}} \mathrm{R}\right)$ and the 5-HT transporter, which would facilitate the development of PH (40). In addition, 5-HTT, 5- $\mathrm{HT}_{1 \mathrm{~B}} \mathrm{R}$, and 5- $\mathrm{HT}_{2 \mathrm{~B}} \mathrm{R}$ are colocalized in pulmonary arteries, and 5- $\mathrm{HT}_{2 \mathrm{~B}} \mathrm{R}$ has been reported to regulate 5-HTT activity in the $1 \mathrm{C} 11$ serotonergic cell line (50). The emerging question, then, is how 5-HTRs control hypoxia-induced PVR.

\subsection{Possible mechanisms relating vascular injuries to 5-HTRs}

Hypoxia changes levels of reactive oxygen species (ROS) and NO in the pulmonary vascular wall, and these alterations are involved in PVR (51). ROS and NO· levels are sensitive to 5-HTR activity. For example, 5- $\mathrm{HT}_{1 \mathrm{~B}} \mathrm{Rs}$ and 5- $\mathrm{HT}_{2 \mathrm{~B}} \mathrm{Rs}$ have been shown to increase NO- levels in human coronary artery endothelial cells (52), and and to elicit relaxation in porcine pulmonary arteries via the release of NO (53). In addition, the $5-\mathrm{HT}_{2 \mathrm{~A}} \mathrm{R}$ induces $\mathrm{NO}$ release by regulating gastrointestinal transit in mice (54), but can inhibit cytokine-stimulated inducible NO· synthase in C6 glioma cells (55). In the cerebral vasculature, NO release from endothelial cells occurs following activation of $5-\mathrm{HT}_{2 \mathrm{~B}} \mathrm{Rs}(56)$. In several cell lines, 5- $\mathrm{HT}_{2 \mathrm{~B}} \mathrm{Rs}$ have been shown to activate both constitutive and inducible NO- synthases via interactions requiring the receptor's C-terminal 
PDZ binding domain (57). In this way, $5-\mathrm{HT}_{2 \mathrm{~B}} \mathrm{R}$ activity leads to $\mathrm{NO}$ generation both in vitro and in vivo.

In renal mesangial cells, 5- $\mathrm{HT}_{2 \mathrm{~A}} \mathrm{R}$ activation induces $\mathrm{ROS}$ (e.g., $\mathrm{H}_{2} \mathrm{O}_{2}$ and superoxide) production via an NAD(P)H oxidase-like enzyme (58). In the hippocampus of mice lacking the 5HTT, increased DNA oxidation has been observed, suggesting that the transporter serves as an antioxidant. However, 5-HTT null mice do not exhibit alterations in glutathione (GSH), oxidized glutathione (GSSG), and other anti-oxidant systems (59). Recently it has been reported that 5$\mathrm{HT}_{2 \mathrm{~B}} \mathrm{R}$ activation can also induce ROS production by a NAD $(\mathrm{P}) \mathrm{H}$ oxidase-dependent mechanism in a serotonergic cell line (60). The mitochondrial electron transport chain is a major ROS source, and mitochondria are a target of $5-\mathrm{HT}_{2 \mathrm{~B}} \mathrm{R}$ anti-apoptotic signaling in cardiomyocytes (61). Thus, 5$\mathrm{HT}_{2 \mathrm{~B}} \mathrm{R}$ signaling leads to changes in both NO and ROS production.

\subsection{Mutation in $5-\mathrm{HT}_{2 \mathrm{~B}} \mathrm{R}$ gene and $\mathrm{PH}$ in human exposed to $\mathrm{DF}$}

Recently, by investigating the $5-\mathrm{HT}_{2 \mathrm{~B}} \mathrm{R}$ gene in patients who developed pulmonary hypertension after intake of DF, a heterozygous mutation was found in one female patient who followed a nine-month anorexigen regimen (62). The polymorphism, R393X, results in a truncation of the receptor's C-terminal tail, thus removing (i) putative palmitoylation and phosphorylation sites essential for internalization, and (ii) the PSD-95, Dlg, ZO-1 (PDZ) binding motif involved in the coupling to NOS and other scaffold proteins. Functionally, the R393X 5-HT ${ }_{2 \mathrm{~B}} \mathrm{R}$ exhibits a loss of rapid internalization compared to the wild type receptor, a finding consistent with removal of Cterminal determinants of receptor trafficking (63). In addition, the R393X 5- $\mathrm{HT}_{2 \mathrm{~B}} \mathrm{R}$ displays diminished coupling to NOS compared with the wild type receptor, as expected from removal of the PDZ binding motif. Despite the apparent losses of function due to the R393X polymorphism, the truncated $5-\mathrm{HT}_{2 \mathrm{~B}} \mathrm{R}$ variant displays striking gain of function vis-à-vis proliferative capacity, an effect that appears to result from a switch from wild type dual $\mathrm{G}_{\mathrm{q}} / \mathrm{G}_{13}$ coupling to a nearly exclusive $\mathrm{G}_{13}$ coupling. Thus, given the role of cell proliferation in PH and PVR, the R393X 5-HT $2 \mathrm{~B}$ polymorphism is clearly relevant for vascular proliferation and remodeling (63). The $\alpha$ subunit of 
$\mathrm{G}_{13}$ plays a critical role in 5-HT $\mathrm{H}_{2 \mathrm{~B}} \mathrm{R}-\mathrm{NOS}$ coupling, (63) and $\mathrm{G}_{13}$ has been reported to activate inducible NOS through a mechanism distinct from that other $\mathrm{G}_{\alpha}$ isoforms (64). Src family kinases (effectors of 5-HT ${ }_{2 \mathrm{~B}} \mathrm{Rs}$ ) (65) act upstream of the small G-protein Rho in $\mathrm{G}_{12 / 13}$-induced JNK activation (66). RhoA and its effector Rho kinase play a major role in the effects of both acute and chronic hypoxia on the pulmonary circulation, possibly by modulating both vasoconstriction and vascular remodeling (67). The increased $\mathrm{G}_{13}$ coupling displayed by the $\mathrm{R} 393 \mathrm{X}$ 5- $\mathrm{HT}_{2 \mathrm{~B}} \mathrm{R}$ likely renders the polymorphism relevant to pathological vasoconstriction and remodeling in response to chronic exposure to DF (Fig. 1).

\section{Control of hypoxia-dependent transcription by 5-HT}

Under low oxygen tension, cells increase the transcription of genes involved in angiogenesis, erythropoiesis, and glycolysis.

\subsection{Transcriptional regulation of 5-HT-related molecules}

Hypoxia causes transcriptional regulation of both the 5-HTT and 5-HTRs. For example, 5$\mathrm{HT}_{1 \mathrm{~B}} \mathrm{R}$ and $5-\mathrm{HT}_{2 \mathrm{~B}} \mathrm{R}$ mRNA levels are increased in the lung vasculature of mice exposed to chronic hypoxia (68), while 5-HT ${ }_{2 A} \mathrm{R}$ expression is unaffected (48). Rat 5-HTT mRNA expression is stimulated in proximal pulmonary arteries and lungs upon chronic hypoxia (33). In humans, DF use for periods greater than three months is associated with an increased risk for developing PH $(6,69)$. DF, a known substrate of 5-HTT, is metabolized in vivo by N-de-ethylation in norDF, which is a potent and selective 5- $\mathrm{HT}_{2 \mathrm{~B}} \mathrm{R}$ agonist $(70,71)$. While $\mathrm{DF}$ does not trigger $\mathrm{PH}$ in mice after 5 weeks under normoxic conditions, administration of the drug does potentiate hypoxia-induced $\mathrm{PH},(48)$ suggesting that hypoxia (like norDF) acts directly on 5-HTRs to contribute to their actions in the pulmonary vasculature. Together, these observations raise the question whether increased expression of 5-HTRs is a prerequisite for PVR, and/or if elevation of 5-HT levels and subsequent activation of basal 5-HTRs can induce PVR in absence of a hypoxic stimulus. 


\subsection{Regulation of cell proliferation by 5-HT molecules}

Hypoxia-induced pulmonary artery vascular cell proliferation triggers PVR, which increases pulmonary artery pressure (72). In vitro, phenotypically distinct SMC subpopulations in the media of bovine main pulmonary artery display differential proliferative responses under extreme hypoxic ( $3 \% \mathrm{O}_{2}$ during 72 hours) conditions: DNA synthesis is increased only in a subset of the medial subpopulations (73). In bovine and rat pulmonary artery SMC, 5-HT induced DNA synthesis (74), and 24 hours under hypoxic conditions can potentiate 5-HT's mitogenic effect (33). Serotonin causes proliferation of many cell types in culture, including vascular SMC, via not only 5-HTRs but also through crosstalk with other signal transduction systems, such as the receptors for the growth factors platelet-derived growth factor (PDGF), fibroblast growth factor, and epidermal growth factor (75). Hypoxia inhibits the release of anti-mitogenic factors such as prostacyclin in cultured pulmonary artery endothelium (76). The absence of hypoxia-induced thymidine incorporation (a measure of cell proliferation) and vascular muscularization in the lungs of hypoxic $5-\mathrm{HT}_{2 \mathrm{~B}} \mathrm{R}^{-/-}$mice indicates an absolute requirement for $5-\mathrm{HT}_{2 \mathrm{~B}} \mathrm{R}$ in chronic hypoxia-induced mitogenesis. Further demonstrating the key role of $5-\mathrm{HT}_{2 \mathrm{~B}} \mathrm{Rs}$ in hypoxia-induced mitosis is the finding that the highly selective 5- $\mathrm{HT}_{2 \mathrm{~B}} \mathrm{R}$ antagonist RS-127445 abrogates proliferation and PVR in wild-type mice exposed to hypoxia (48).

Activation of MAPK, another mediator of proliferative signals, has also been implicated in PVR (44). PDGF causes proliferation in pulmonary arterial SMC (77) and increased expression of PDGF has been reported in rat lungs subsequent to hypoxic PH (78). In mouse fibroblast LMTK cells stably expressing murine 5- $\mathrm{HT}_{2 \mathrm{~B}} \mathrm{Rs}, 5$-HT-induced receptor activation leads to cell cycle progression via a complex signaling pathway in which the cytoplasmic tyrosine kinase c-Src controls cyclin E expression and, in concert with PDGF receptor transactivation, induces cyclin D1 expression in a MAPK-dependent fashion (65).

In sheep with hypoxia-induced PH, increased mRNA levels of the transforming growth factor- $\beta$ (TGF- $\beta$ ) have been associated with PVR (79). It has been suggested that interleukins (ILs) 
and tumor necrosis factor (TNF)- $\alpha$ are also involved in the development of PVR: serum

concentrations of IL-1 and IL-6 are increased in patients with primary PH (80); IL-1 is a mitogenic factor in human and rat vascular SMC (81); hypoxia stimulates IL-1 production in human vascular SMC (82), and NF-IL6 activates IL-6 gene transcription in hypoxic pulmonary vascular endothelial cells (83). Chronic hypoxia $\left(10 \% \mathrm{O}_{2}\right.$ for 5 weeks) also causes increased TGF- $\beta$ levels lung vessel culture supernatants via a mechanism that requires $5-\mathrm{HT}_{2 \mathrm{~B}} \mathrm{R}$ activity (48). The release of TNF- $\alpha$, IL-1 $\beta$, and IL-6 in response by isoproterenol-treated cardiac fibroblasts is also 5- $\mathrm{HT}_{2 \mathrm{~B}} \mathrm{R}$-dependent (84).

Matrix metalloproteinases (MMPs) activation and extracellular matrix (ECM) remodeling contribute to hypoxia-induced pulmonary vascular proliferation in PVR. Some of the best characterized ECM substrates for MMPs are collagens, elastin, and proteoglycans (9). An increase in elastase activity leads to the release of latent growth factors (85) and elastase activity is increased in mice with chronic hypoxia-induced $\mathrm{PH}$ (86), an effect that is absent upon genetic or pharmacological ablation of $5-\mathrm{HT}_{2 \mathrm{~B}} \mathrm{Rs}(48)$. These observations suggest that $5-\mathrm{HT}_{2 \mathrm{~B}} \mathrm{R}$-dependent elastase activity leads to latent growth factor release including TGF- $\beta$. In addition, collagenolytic activity in extracts from pulmonary arteries in rats exposed to hypoxia is increased (87) that may include MMP activity contributing to PVR. A possible role for $5-\mathrm{HT}_{2 \mathrm{~B}} \mathrm{R}$ in the activation of various MMPs in PVR is likely, given that activation of MMP-2 (ECM substrates: various collagens, fibronectin, laminin, aggrecan, insoluble elastin) and MMP-9 (ECM substrates: various collagens) is regulated by $5-\mathrm{HT}_{2 \mathrm{~A}} \mathrm{Rs}$ in uterine tissue (88) and by $5-\mathrm{HT}_{2 \mathrm{~B}} \mathrm{Rs}$ in cardiac fibroblasts (LM unpublished). Recently, the $5-\mathrm{HT}_{2 \mathrm{~B}} \mathrm{R}$ was shown to stimulate TNF- $\alpha$ converting enzyme in a serotonergic cell line (60). Thus, 5- $\mathrm{HT}_{2} \mathrm{R}$ appears to be crucial for hypoxia-induced PVR via MMPregulated growth factor expression in the lung vasculature (Fig. 2). 


\section{Regulation of transcription factors expression by 5-HT molecules}

Hypoxic transcription processes are coordinately regulated by the hypoxia-inducible factor HIF-1, which, despite its constitutive expression, is only active in response to reduced $\mathrm{O}_{2}$ levels (89). Several line of experimental evidence support the hypothesis that factors controlling HIF-1 expression also contribute to hypoxia-induced PVR. Indeed, a strong correlation has been found between HIF-1 $\alpha$ overexpression and immunoreactivity of the cell proliferation index Ki67 (90). Though hypoxia is the ubiquitous inducer of HIF-1 $\alpha$, other stimuli, such as insulin, insulin-like growth factors 1 and 2, and EGF, also increase HIF-1 $\alpha$ protein levels in some cells. These stimuli also induce VEGF expression in an HIF-1-dependent manner.

\subsection{Putative regulation of HIF molecules by 5-HT}

The $\mathrm{O}_{2}$-regulated transcription factor HIF-1 has been proposed to control the expression of several agents involved in PVR, such as endothelin-1 and TGF- $\beta$ (91). HIF-1 $\alpha$ hypomorphic mice develop less severe medial wall thickening in the pulmonary arterioles than do wild type mice maintained for 3 weeks at $10 \% \mathrm{O}_{2}(92)$. Other factors, such as angiotensin II (Ang II), thrombin, platelet-derived growth factor, can increase HIF-1 $\alpha$ in vascular SMC to levels beyond those resulting from hypoxic treatment. The non-hypoxic induction of the HIF-1 transcription factor via vasoactive hormones (Ang II and thrombin) is triggered by a dual mechanism, i.e., PKC-mediated transcriptional activation and ROS-dependent increases in HIF-1 $\alpha$ protein expression (93). In 5$\mathrm{HT}_{2 \mathrm{~B}} \mathrm{R}$-expressing cells, receptor activation increases the activity of the c-Src family tyrosine kinase and ROS levels through NAD(P)H oxidase $(60,65)$, which can thus induce HIF-1 $\alpha$ expression.

\subsection{Hypoxia-induced NF- $\kappa$ B expression by $5-\mathrm{HT}_{2 \mathrm{~B}} \mathrm{Rs}$}

In cardiomyocytes, 5- $\mathrm{HT}_{2 \mathrm{~B}} \mathrm{Rs}$, via phosphatidylinositol-3 kinase/Akt, activate NF- $\mathrm{KB}$, an event that is required for the receptors' anti-apoptotic effects (61). Activation of NF-אB is sufficient

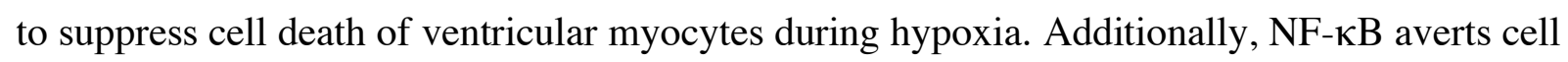
death through a mechanism that prevents perturbations to the mitochondrion during hypoxic injury (94). Moreover, the 5- $\mathrm{HT}_{2 \mathrm{~B}} \mathrm{R}$ has recently been identified in a large-scale screen for human genes 
that activate NF- $\mathrm{BB}$ signaling pathways (95). Furthermore, treatment with LY294002 (a selective inhibitor of phosphatidylinositol 3-kinase) significantly inhibits erythropoietin protein and mRNA expression in Hep3B cells exposed to hypoxia for 24 hours. Inhibition of NF-אB with a superrepressor (dominant negative IאB $\alpha$ ) also significantly blocks HIF-1 transactivation, as well as erythropoietin gene expression ${ }^{129}$. We propose that $5-\mathrm{HT}_{2 \mathrm{~B}} \mathrm{R}$ expression, which is increased under hypoxic conditions, is a trigger of HIF-1 $\alpha$ via phosphatidylinositol-3 kinase/Akt/NF- $\kappa$ B pathway.

\subsection{Hypoxia-induced NF- $\mathrm{B}$ may regulate HIF expression}

Putative control of HIF-1 by 5-HT ${ }_{2 \mathrm{~B}}$ Rs would explain why the expression of PVR-inducing factors, such as endothelin-1 and TGF- $\beta$ (both of which are HIF-1-regulated), is not modified in hypoxic 5- $\mathrm{HT}_{2 \mathrm{~B}} \mathrm{R}^{-/}$mice. A recent study by Moncada's group (96) showed that upon hypoxia, inhibition of mitochondrial respiration by $\mathrm{NO} \cdot$ leads to a redistribution of intracellular $\mathrm{O}_{2}$ toward other $\mathrm{O}_{2}$-dependent targets, such as prolyl hydroxylase, which causes the constitutive degradation of HIF-1 $\alpha$. Stimulation of the NO/PKG pathway in rats treated with sildenafil increases RhoA protein levels, phosphorylation, and association with RhoGDI in the pulmonary artery, effects opposite to those induced by chronic inhibition of NO· synthesis or hypoxia. The observed NO· alterations in the hypoxic pulmonary vascular wall lead to a plausible explanation for the absence of hypoxiainduced PVR in 5- $\mathrm{HT}_{2 \mathrm{~B}} \mathrm{R}^{-/}$mice and further strengthen the hypothesis that $5-\mathrm{HT}_{2 \mathrm{~B}} \mathrm{R}$ expression under hypoxic conditions is not a target but a trigger of HIF-1 (Fig. 3).

\section{Pressing Questions}

Determining of the contribution of 5-HT to hypoxic responses in lung endothelial cells, smooth muscle cells, and fibroblasts is of major importance. How and when do these different cell types participate in the development and/or progression of $\mathrm{PH}$ ? Of particular interest is the origin of the process. Do normoxic endothelial, fibroblast, and /or smooth muscles cells respond to 5-HT in a similar way as hypoxic cells? When does irreversible commitment to hypoxia-induced PVR occur? Given that most studies have focused on lung vasoconstrictive factors, how closely does 
development of the pathology follow that of vasoconstriction? Finally, is the developmental program that generates lung vessels in the embryo retained in the lung vasculature of the adult? Is this program reactivated in adult lung pathophysiology? The answers to these questions will provide general insights into the pathogenesis of $\mathrm{PH}$ and may suggest novel therapeutic approaches to treating lung diseases in humans. 


\section{References}

1. Semenza, G.L., Perspectives on oxygen sensing. Cell, 1999. 98: p. 281-284.

2. Yuan, X.J., M.L. Tod, L.J. Rubin and M.P. Blaustein, Contrasting effects of hypoxia on tension in rat pulmonary and mesenteric arteries. Am J Physiol, 1990. 259: p. H281-289.

3. Egermayer, P., G.I. Town and A.J. Peacock, Role of serotonin in the pathogenesis of acute and chronic pulmonary hypertension. Thorax, 1999. 54: p. 161-168.

4. Villalón, C.M., P. de Vries and P.R. Saxena, Serotonin receptors as cardiovascular targets. Drug Discovery Today, 1997. 2: p. 294-300.

5. Rubin, L.J., Cellular and molecular mechanisms responsible for the pathogenesis of primary pulmonary hypertension. Pediatr Pulmonol Suppl, 1999. 18: p. 194-197.

6. Rich, S., Primary Pulmonary Hypertension. Curr Treat Options Cardiovasc Med, 2000. 2: p. 135-140.

7. Reeves, J.T., B.M. Groves and D. Turkevich, The case for treatment of selected patients with primary pulmonary hypertension. Am Rev Respir Dis, 1986. 134: p. 342-346.

8. Aaronson, P.I., T.P. Robertson and J.P. Ward, Endothelium-derived mediators and hypoxic pulmonary vasoconstriction. Respir Physiol Neurobiol, 2002. 132: p. 107-120.

9. Novotna, J. and J. Herget, Possible role of matrix metalloproteinases in reconstruction of peripheral pulmonary arteries induced by hypoxia. Physiol Res, 2002. 51: p. 323-334.

10. Raymond, J.R., Y.V. Mukhin, A. Gelasco, J. Turner, G. Collinsworth, T.W. Gettys, J.S. Grewal and M.N. Garnovskaya, Multiplicity of mechanisms of serotonin receptor signal transduction. Pharmacol Ther, 2001. 92: p. 179-212.

11. Kuang, S., S.A. Doran, R.J. Wilson, G.G. Goss and J.I. Goldberg, Serotonergic sensorymotor neurons mediate a behavioral response to hypoxia in pond snail embryos. $\mathrm{J}$ Neurobiol, 2002. 52: p. 73-83.

12. Kinkead, R. and G.S. Mitchell, Time-dependent hypoxic ventilatory responses in rats: effects of ketanserin and 5-carboxamidotryptamine. Am J Physiol, 1999. 277: p. R658-666.

13. McGuire, M., Y. Zhang, D.P. White and L. Ling, Serotonin receptor subtypes required for ventilatory long-term facilitation and its enhancement after chronic intermittent hypoxia in awake rats. Am J Physiol Regul Integr Comp Physiol, 2004. 286: p. R334-341.

14. Kirby, G.C. and D.S. McQueen, Effects of the antagonists MDL 72222 and ketanserin on responses of cat carotid body chemoreceptors to 5-hydroxytryptamine. Br J Pharmacol, 1984. 83: p. 259-269.

15. Fu, X.W., C.A. Nurse, V. Wong and E. Cutz, Hypoxia-induced secretion of serotonin from intact pulmonary neuroepithelial bodies in neonatal rabbit. J Physiol, 2002. 539: p. 503-510.

16. Farber, H.W. and J. Loscalzo, Pulmonary arterial hypertension. N Engl J Med, 2004. 351: p. 1655-1665.

17. Hervé, P., L. Drouet, C. Dosquet, J.M. Launay, B. Rain, G. Simonneau, J. Caen and P. Duroux, Primary pulmonary hypertension in a patient with a familial platelet storage pool disease: role of serotonin. Am J Med, 1990. 89: p. 117-120.

18. Hervé, P., J.M. Launay, M.L. Scrobohaci, F. Brenot, G. Simonneau, P. Petitpretz, P. Poubeau, J. Cerrina, P. Duroux and L. Drouet, Increased plasma serotonin in primary pulmonary hypertension. Am J Med, 1995. 99: p. 249-254.

19. Kéreveur, A., J. Callebert, M. Humbert, P. Hervé, G. Simonneau, J.M. Launay and L. Drouet, High plasma serotonin levels in primary pulmonary hypertension : effect of longterm epoprostenol (Prostacyclin) therapy. Arterioscler Thromb Vasc Biol, 2000. 20: p. 2233-2239.

20. Kentera, D., D. Susic, V. Veljkovic, G. Tucakovic and V. Koko, Pulmonary artery pressure in rats with hereditary platelet function defect. Respiration, 1988. 54: p. 110-114.

21. Sato, K., S. Webb, A. Tucker, M. Rabinovitch, R.F. O'Brien, I.F. McMurtry and T.J. Stelzner, Factors influencing the idiopathic development of pulmonary hypertension in the fawn hooded rat. Am Rev Respir Dis, 1992. 145: p. 793-797. 
22. Vane, J.R., Br. J. Pharmacol., 1957. 112: p. 344-349.

23. McDonald, T.P., M. Cottrell and R. Clift, Effects of short-term hypoxia on platelet counts of mice. Blood, 1978. 51: p. 165-175.

24. McDonald, T.P., M.B. Cottrell, S.A. Steward, R.E. Clift, C.J. Swearingen and C.W. Jackson, Comparison of platelet production in two strains of mice with different modal megakaryocyte DNA ploidies after exposure to hypoxia. Exp Hematol, 1992. 20: p. 51-56.

25. Li, N., N.H. Wallen, M. Ladjevardi and P. Hjemdahl, Effects of serotonin on platelet activation in whole blood. Blood Coagul Fibrinolysis, 1997. 8: p. 517-523.

26. Rostagno, C., D. Prisco, M. Boddi and L. Poggesi, Evidence for local platelet activation in pulmonary vessels in patients with pulmonary hypertension secondary to chronic obstructive pulmonary disease. Eur Respir J, 1991. 4: p. 147-151.

27. Steele, P., J.H. Ellis, Jr., H.S. Weily and E. Genton, Platelet survival time in patients with hypoxemia and pulmonary hypertension. Circulation, 1977. 55: p. 660-661.

28. Keith, I.M., J.A. Will, R.J. Huxtable and K. Weir, Anti-platelet agents reduce morphological changes of chronic hypoxic pulmonary hypertension. Histol Histopathol, 1987. 2: p. 203206.

29. Fanburg, B.L. and S.L. Lee, A role for the serotonin transporter in hypoxia-induced pulmonary hypertension. J Clin Invest, 2000. 105: p. 1521-1523.

30. Cook, E.H., Jr., K.E. Fletcher, M. Wainwright, N. Marks, S.Y. Yan and B.L. Leventhal, Primary structure of the human platelet serotonin 5-HT2A receptor: identify with frontal cortex serotonin 5-HT2A receptor. J Neurochem, 1994. 63: p. 465-469.

31. De Chaffoy de Courcelles, D. and F. De Clerck, The human platelet 5-HT2-receptor: an update, in Cardiovascular Pharmacology of 5-Hydroxytryptamine, P.R. Saxena, D.I. Wallis, W. Wouters, and P. Bevan, Editors. 1990, Kluwer: Dordrecht. p. 445-457.

32. Davidson, C. and J.A. Stamford, Serotonin efflux in the rat ventral lateral geniculate nucleus assessed by fast cyclic voltammetry is modulated by 5-HT1B and 5-HT1D autoreceptors. Neuropharmacology, 1996. 35: p. 1627-1634.

33. Eddahibi, S., V. Fabre, C. Boni, M.P. Martres, B. Raffestin, M. Hamon and S. Adnot, Induction of serotonin transporter by hypoxia in pulmonary vascular smooth muscle cells. Relationship with the mitogenic action of serotonin. Circ Res, 1999. 84: p. 329-336.

34. Bhat, G.B. and E.R. Block, Hypoxia directly increases serotonin transport by porcine pulmonary artery endothelial cell plasma membrane vesicles. Am J Respir Cell Mol Biol, 1990. 3: p. 363-367.

35. MacLean, M.R., G.A. Deuchar, M.N. Hicks, I. Morecroft, S. Shen, J. Sheward, J. Colston, L. Loughlin, M. Nilsen, Y. Dempsie and A. Harmar, Overexpression of the 5hydroxytryptamine transporter gene: effect on pulmonary hemodynamics and hypoxiainduced pulmonary hypertension. Circulation, 2004. 109: p. 2150-2155.

36. Lee, S.L., W.W. Wang, B.J. Moore and B.L. Fanburg, Dual effect of serotonin on growth of bovine pulmonary artery smooth muscle cells in culture. Circ Res, 1991. 68: p. 1362-1368.

37. Marcos, E., S. Adnot, M.H. Pham, A. Nosjean, B. Raffestin, M. Hamon and S. Eddahibi, Serotonin transporter inhibitors protect against hypoxic pulmonary hypertension. Am J Respir Crit Care Med, 2003. 168: p. 487-493.

38. Pitt, B.R., W. Weng, A.R. Steve, R.D. Blakely, I. Reynolds and P. Davies, Serotonin increases DNA synthesis in rat proximal and distal pulmonary vascular smooth muscle cells in culture. Am J Physiol, 1994. 266: p. L178-186.

39. Sanchez, C. and J. Hyttel, Comparison of the effects of antidepressants and their metabolites on reuptake of biogenic amines and on receptor binding. Cell. Mol. Neurobiol., 1999. 19: p. 467-489.

40. Morecroft, I., L. Loughlin, M. Nilsen, J. Colston, Y. Dempsie, J. Sheward, A. Harmar and M.R. MacLean, Functional interactions between 5-hydroxytryptamine receptors and the serotonin transporter in pulmonary arteries. J Pharmacol Exp Ther, 2005. 313: p. 539-548. 
41. Ni, W., C.S. Wilhelm, M. Bader, D.L. Murphy, K.J. Lookingland and S.W. Watts, (+)Norfenfluramine-induced arterial contraction is not dependent on endogenous 5-HT or 5HTT. J Pharmacol Exp Ther, 2005.

42. Rabinovitch, M., Linking a serotonin transporter polymorphism to vascular smooth muscle proliferation in patients with primary pulmonary hypertension. J Clin Invest, 2001. 108: p. 1109-1111.

43. Eddahibi, S., N. Hanoun, L. Lanfumey, K.P. Lesch, B. Raffestin, M. Hamon and S. Adnot, Attenuated hypoxic pulmonary hypertension in mice lacking the 5-hydroxytryptamine transporter gene. J Clin Invest, 2000. 105: p. 1555-1562.

44. Jeffery, T.K. and J.C. Wanstall, Pulmonary vascular remodeling: a target for therapeutic intervention in pulmonary hypertension. Pharmacol Ther, 2001. 92: p. 1-20.

45. Keegan, A., I. Morecroft, D. Smillie, M.N. Hicks and M.R. MacLean, Contribution of the 5HT1B receptor to hypoxia-induced pulmonary hypertension. Converging evidence using 5HT1B-receptor knockout mice and the 5-HT1B/1D-receptor antagonist GR127935. Circ Res, 2001. 89: p. 1231-1229.

46. Angeles, D.M., J. Williams, R.E. Purdy, L. Zhang and W.J. Pearce, Effects of maturation and acute hypoxia on receptor-IP(3) coupling in ovine common carotid arteries. Am J Physiol Regul Integr Comp Physiol, 2001. 280: p. R410-417.

47. Angeles, D.M., J. Williams, L. Zhang and W.J. Pearce, Acute hypoxia modulates 5-HT receptor density and agonist affinity in fetal and adult ovine carotid arteries. Am J Physiol Heart Circ Physiol, 2000. 279: p. H502-510.

48. Launay, J.M., P. Hervé, K. Peoc'h, C. Tournois, J. Callebert, C. Nebigil, N. Etienne, L. Drouet, M. Humbert, G. Simonneau and L. Maroteaux, Function of the serotonin 5hydroxytryptamine $2 \mathrm{~B}$ receptor in pulmonary hypertension. Nat Med, 2002. 8: p. 11291135 .

49. Tournois, C., V. Mutel, P. Manivet, J.M. Launay and O. Kellermann, Cross-talk between 5hydroxytryptamine receptors in a serotonergic cell line. Involvement of arachidonic acid metabolism. J Biol Chem, 1998. 273: p. 17498-17503.

50. Launay, J.M., S. Loric, V. Mutel and O. Kellermann, The 5-HT2B receptor controls the overall 5-HT transport system in the 1C11 serotonergic cell line. Ann N Y Acad Sci, 1998. 861: p. 247.

51. Hampl, V. and J. Herget, Role of nitric oxide in the pathogenesis of chronic pulmonary hypertension. Physiol Rev, 2000. 80: p. 1337-1372.

52. Ishida, T., S. Kawashima, K. Hirata and M. Yokoyama, Nitric oxide is produced via 5HT1B and 5-HT2B receptor activation in human coronary artery endothelial cells. Kobe J Med Sci, 1998. 44: p. 51-63.

53. Glusa, E. and H.H. Pertz, Further evidence that 5-HT-induced relaxation of pig pulmonary artery is mediated by endothelial 5-HT2B receptors. Br J Pharmacol, 2000. 130: p. 692-698.

54. Matsuda, H., Y. Li and M. Yoshikawa, Possible involvement of 5-HT and 5-HT2 receptors in acceleration of gastrointestinal transit by escin Ib in mice. Life Sci, 2000. 66: p. 22332238.

55. Miller, K.J. and H.A. Gonzalez, Serotonin 5-HT2A receptor activation inhibits cytokinestimulated inducible nitric oxide synthase in C6 glioma cells. Ann N Y Acad Sci, 1998. 861: p. 169-173.

56. Fozard, J.R., The 5-hydroxytryptamine-nitric oxide connection: the key link in the initiation of migraine? Arch Int Pharmacodyn Ther, 1995. 329: p. 111-119.

57. Manivet, P., S. Mouillet-Richard, J. Callebert, C.G. Nebigil, L. Maroteaux, S. Hosoda, O. Kellermann and J.-M. Launay, PDZ-dependent activation of nitric-oxide synthases by the serotonin 2B receptor. J Biol Chem, 2000. 275: p. 9324-9331.

58. Grewal, J.S., Y.V. Mukhin, M.N. Garnovskaya, J.R. Raymond and E.L. Greene, Serotonin 5-HT2A receptor induces TGF-beta1 expression in mesangial cells via ERK: proliferative and fibrotic signals. Am J Physiol, 1999. 276: p. F922-930. 
59. Mossner, R., R. Dringen, A.M. Persico, B. Janetzky, O. Okladnova, D. Albert, M. Gotz, J. Benninghoff, A. Schmitt, M. Gerlach, P. Riederer and K.P. Lesch, Increased hippocampal DNA oxidation in serotonin transporter deficient mice. J Neural Transm, 2002. 109: p. 557565.

60. Pietri, M., B. Schneider, S. Mouillet-Richard, M. Ermonval, V. Mutel, J.-M. Launay and O. Kellermann, Reactive oxygen species-dependent TNF-alpha converting enzyme activation trough stimulation of 5-HT2B and alpha1D autoreceptors in neuronal cells. Faseb J, 2005. 19: p. 1078-1087.

61. Nebigil, C.G., N. Etienne, N. Messaddeq and L. Maroteaux, Serotonin is a novel survival factor of cardiomyocytes: mitochondria as a target of 5-HT2B-receptor signaling. FASEB J, 2003. 17: p. 1373-1375.

62. Blanpain, C., E. Le Poul, J. Parma, C. Knoop, M. Detheux, M. Parmentier, G. Vassart and M.J. Abramowicz, Serotonin 5-HT2B receptor loss of function mutation in a patient with fenfluramine-associated primary pulmonary hypertension. Cardiovasc Res, 2003. 60: p. 518528.

63. Deraet, M., P. Manivet, A. Janoshazi, J. Callebert, S. Guenther, L. Drouet, J.M. Launay and L. Maroteaux, The natural mutation encoding a $\mathrm{C}$ terminus-truncated 5-

Hydroxytryptamine2B receptor is a gain of proliferative functions. Mol Pharmacol, 2005. 67: p. 983-991.

64. Kitamura, K., W.D. Singer, R.A. Star, S. Muallem and R.T. Miller, Induction of inducible nitric-oxide synthase by the heterotrimeric G protein Galpha13. J Biol Chem, 1996. 271: p. $7412-7415$.

65. Nebigil, C.G., J.-M. Launay, P. Hickel, C. Tournois and L. Maroteaux, 5Hydroxytryptamine $2 \mathrm{~B}$ receptor regulates cell-cycle progression: Cross talk with tyrosine kinase pathways. Proc Natl Acad Sci U S A, 2000. 97: p. 2591-2596.

66. Nagao, M., Y. Kaziro and H. Itoh, The Src family tyrosine kinase is involved in Rhodependent activation of c-Jun N-terminal kinase by Galpha12. Oncogene, 1999. 18: p. 44254434.

67. Fagan, K.A., M. Oka, N.R. Bauer, S.A. Gebb, D.D. Ivy, K.G. Morris and I.F. McMurtry, Attenuation of acute hypoxic pulmonary vasoconstriction and hypoxic pulmonary hypertension in mice by inhibition of Rho-kinase. Am J Physiol Lung Cell Mol Physiol, 2004. 287: p. L656-664.

68. Rondelet, B., R. Van Beneden, F. Kerbaul, S. Motte, P. Fesler, K. McEntee, S. Brimioulle, J.M. Ketelslegers and R. Naeije, Expression of the serotonin $1 \mathrm{~b}$ receptor in experimental pulmonary hypertension. Eur Respir J, 2003. 22: p. 408-412.

69. Abenhaim, L., Y. Moride, F. Brenot, S. Rich, J. Benichou, X. Kurz, T. Higenbottam, C. Oakley, E. Wouters, M. Aubier, G. Simonneau and B. Begaud, Appetite-suppressant drugs and the risk of primary pulmonary hypertension. International Primary Pulmonary Hypertension Study Group. N Engl J Med, 1996. 335: p. 609-616.

70. Fitzgerald, L.W., T.C. Burn, B.S. Brown, J.P. Patterson, M.H. Corjay, P.A. Valentine, J.-H. Sun, J.R. Link, I. Abbaszade, J.M. Hollis, B.L. Largent, P.R. Hartig, G.F. Hollis, P.C. Meunier, A.J. Robichaud and D.W. Robertson, Possible role of valvular serotonin 5-HT2B receptors in the cardiopathy associated with fenfluramine. Mol Pharmacol, 2000. 57: p. 7581.

71. Rothman, R.B., M.H. Baumann, J.E. Savage, L. Rauser, A. McBride, S.J. Hufeisen and B.L. Roth, Evidence for possible involvement of 5-HT2B receptors in the cardiac valvulopathy associated with fenfluramine and other serotonergic medications. Circulation, 2000. 102: p. 2836-2841.

72. Loscalzo, J., Genetic clues to the cause of primary pulmonary hypertension. N Engl J Med, 2001. 345: p. 367-371. 
73. Frid, M.G., E.C. Dempsey, A.G. Durmowicz and K.R. Stenmark, Smooth muscle cell heterogeneity in pulmonary and systemic vessels. Importance in vascular disease.

Arterioscler Thromb Vasc Biol, 1997. 17: p. 1203-1209.

74. Lee, S.L., W.W. Wang, J.J. Lanzillo and B.L. Fanburg, Regulation of serotonin-induced DNA synthesis of bovine pulmonary artery smooth muscle cells. Am J Physiol, 1994. 266: p. L53-60.

75. Fanburg, B.L. and S.L. Lee, A new role for an old molecule: serotonin as a mitogen. Am J Physiol, 1997. 272: p. L795-806.

76. Madden, M.C., R.L. Vender and M. Friedman, Effect of hypoxia on prostacyclin production in cultured pulmonary artery endothelium. Prostaglandins, 1986. 31: p. 1049-1062.

77. Rothman, A., B. Wolner, D. Button and P. Taylor, Immediate-early gene expression in response to hypertrophic and proliferative stimuli in pulmonary arterial smooth muscle cells. J Biol Chem, 1994. 269: p. 6399-6404.

78. Katayose, D., M. Ohe, K. Yamauchi, M. Ogata, K. Shirato, H. Fujita, S. Shibahara and T. Takishima, Increased expression of PDGF A- and B-chain genes in rat lungs with hypoxic pulmonary hypertension. Am J Physiol, 1993. 264: p. L100-106.

79. Perkett, E.A., R.W. Pelton, B. Meyrick, L.I. Gold and D.A. Miller, Expression of transforming growth factor-beta mRNAs and proteins in pulmonary vascular remodeling in the sheep air embolization model of pulmonary hypertension. Am J Respir Cell Mol Biol, 1994. 11: p. 16-24.

80. Humbert, M., G. Monti, F. Brenot, O. Sitbon, A. Portier, L. Grangeot-Keros, P. Duroux, P. Galanaud, G. Simonneau and D. Emilie, Increased interleukin-1 and interleukin-6 serum concentrations in severe primary pulmonary hypertension. Am J Respir Crit Care Med, 1995. 151: p. 1628-1631.

81. Wang, X., B.R. Wang, X.L. Duan, P. Zhang, Y.Q. Ding, Y. Jia, X.Y. Jiao and G. Ju, Strong expression of interleukin-1 receptor type I in the rat carotid body. J Histochem Cytochem, 2002. 50: p. 1677-1684.

82. Cooper, A.L. and D. Beasley, Hypoxia stimulates proliferation and interleukin-1alpha production in human vascular smooth muscle cells. Am J Physiol, 1999. 277: p. H13261337.

83. Yan, S.F., I. Tritto, D. Pinsky, H. Liao, J. Huang, G. Fuller, J. Brett, L. May and D. Stern, Induction of interleukin 6 (IL-6) by hypoxia in vascular cells. Central role of the binding site for nuclear factor-IL-6. J Biol Chem, 1995. 270: p. 11463-11471.

84. Jaffré, F., J. Callebert, A. Sarre, N. Etienne, C.G. Nebigil, J.M. Launay, L. Maroteaux and L. Monassier, Involvement of the serotonin 5-HT2B receptor in cardiac hypertrophy linked to sympathetic stimulation: control of interleukin- 6 , interleukin-1 beta, and tumor necrosis factor-alpha cytokine production by ventricular fibroblasts. Circulation, 2004. 110: p. 969974.

85. Thompson, K. and M. Rabinovitch, Exogenous leukocyte and endogenous elastases can mediate mitogenic activity in pulmonary artery smooth muscle cells by release of extracellular-matrix bound basic fibroblast growth factor. J Cell Physiol, 1996. 166: p. 495505.

86. Maruyama, K., C.L. Ye, M. Woo, H. Venkatacharya, L.D. Lines, M.M. Silver and M. Rabinovitch, Chronic hypoxic pulmonary hypertension in rats and increased elastolytic activity. Am J Physiol, 1991. 261: p. H1716-1726.

87. Novotna, J. and J. Herget, Exposure to chronic hypoxia induces qualitative changes of collagen in the walls of peripheral pulmonary arteries. Life Sci, 1998. 62: p. 1-12.

88. Wilcox, B.D., L. Rydelek-Fitzgerald and J.J. Jeffrey, Regulation of uterine collagenase gene expression: interactions between serotonin and progesterone. Mol Cell Endocrinol, 1994. 101: p. 67-75.

89. Semenza, G.L., HIF-1, O(2), and the 3 PHDs: how animal cells signal hypoxia to the nucleus. Cell, 2001. 107: p. 1-3. 
90. Zhong, H., A.M. De Marzo, E. Laughner, M. Lim, D.A. Hilton, D. Zagzag, P. Buechler, W.B. Isaacs, G.L. Semenza and J.W. Simons, Overexpression of hypoxia-inducible factor 1alpha in common human cancers and their metastases. Cancer Res, 1999. 59: p. 5830-5835.

91. Semenza, G.L., Expression of hypoxia-inducible factor 1: mechanisms and consequences. Biochem Pharmacol, 2000. 59: p. 47-53.

92. Yu, A.Y., L.A. Shimoda, N.V. Iyer, D.L. Huso, X. Sun, R. McWilliams, T. Beaty, J.S. Sham, C.M. Wiener, J.T. Sylvester and G.L. Semenza, Impaired physiological responses to chronic hypoxia in mice partially deficient for hypoxia-inducible factor 1alpha. J Clin Invest, 1999. 103: p. 691-696.

93. Page, E.L., G.A. Robitaille, J. Pouyssegur and D.E. Richard, Induction of hypoxia-inducible factor-1alpha by transcriptional and translational mechanisms. J Biol Chem, 2002. 277: p. 48403-48409.

94. Regula, K.M., D. Baetz and L.A. Kirshenbaum, Nuclear factor-kappaB represses hypoxiainduced mitochondrial defects and cell death of ventricular myocytes. Circulation, 2004. 110: p. 3795-3802.

95. Matsuda, A., Y. Suzuki, G. Honda, S. Muramatsu, O. Matsuzaki, Y. Nagano, T. Doi, K. Shimotohno, T. Harada, E. Nishida, H. Hayashi and S. Sugano, Large-scale identification and characterization of human genes that activate NF-kappaB and MAPK signaling pathways. Oncogene, 2003. 22: p. 3307-3318.

96. Hagen, T., C.T. Taylor, F. Lam and S. Moncada, Redistribution of intracellular oxygen in hypoxia by nitric oxide: effect on HIF1alpha. Science, 2003. 302: p. 1975-1978. 


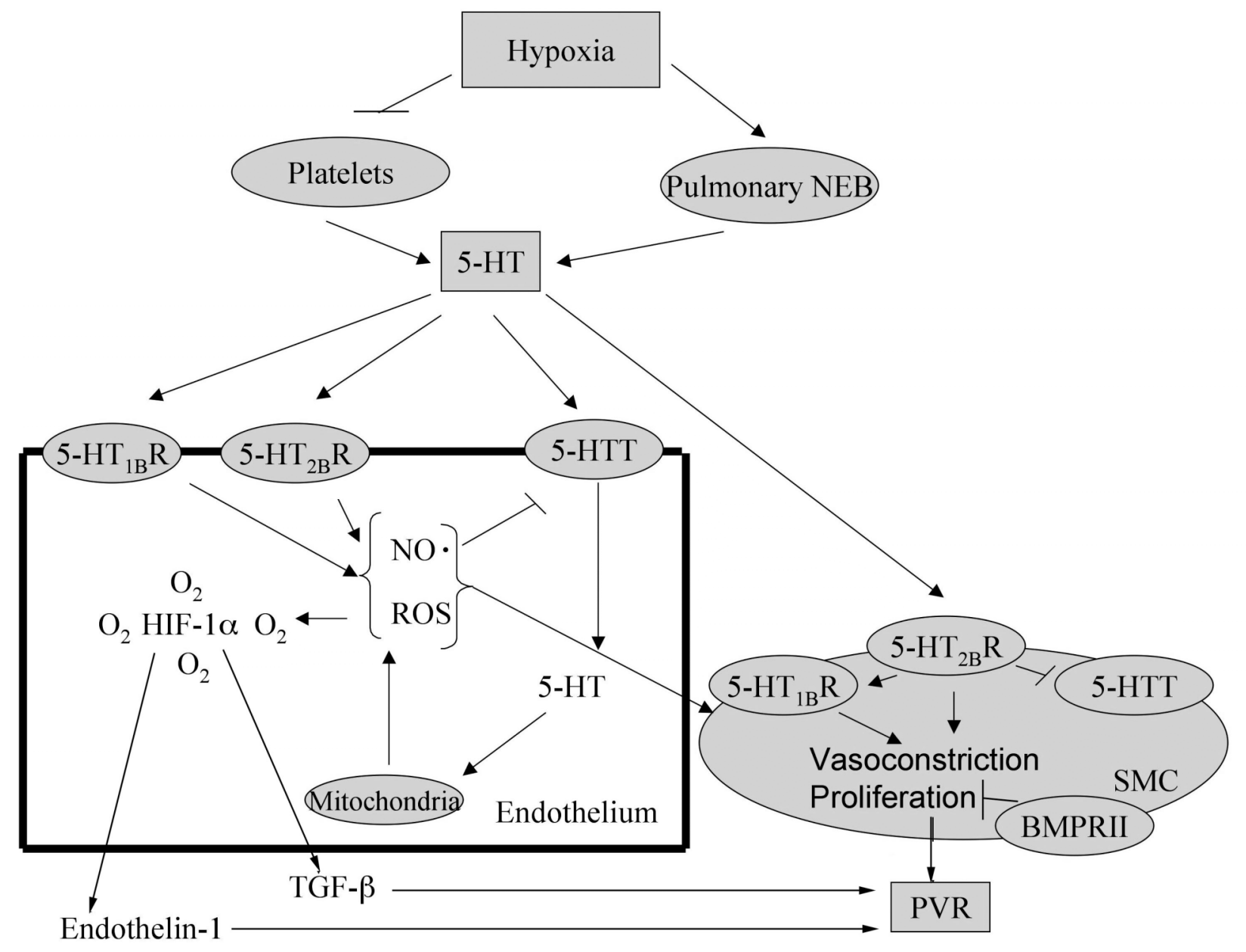

Figure 1. 5-HT in hypoxia-induced PVR. Hypoxia raises 5-HT levels by operating at platelets and pulmonary NEB, which acts at 5-HT ${ }_{2 B} \mathrm{R}, 5-\mathrm{HT}_{1 \mathrm{~B}} \mathrm{R}$ and 5-HTT. Changes in ROS and NO levels upon hypoxia, result in endothelium and vascular SMC oxidative damage and death. ProPVR agents, such as endothelin-1 and TGF- $\beta$, have no effect on PVR in the absence of 5$\mathrm{HT}_{2 \mathrm{~B}} \mathrm{Rs}$. Lines with arrows indicate positive actions and with a $\mathrm{T}$ negative effects. 


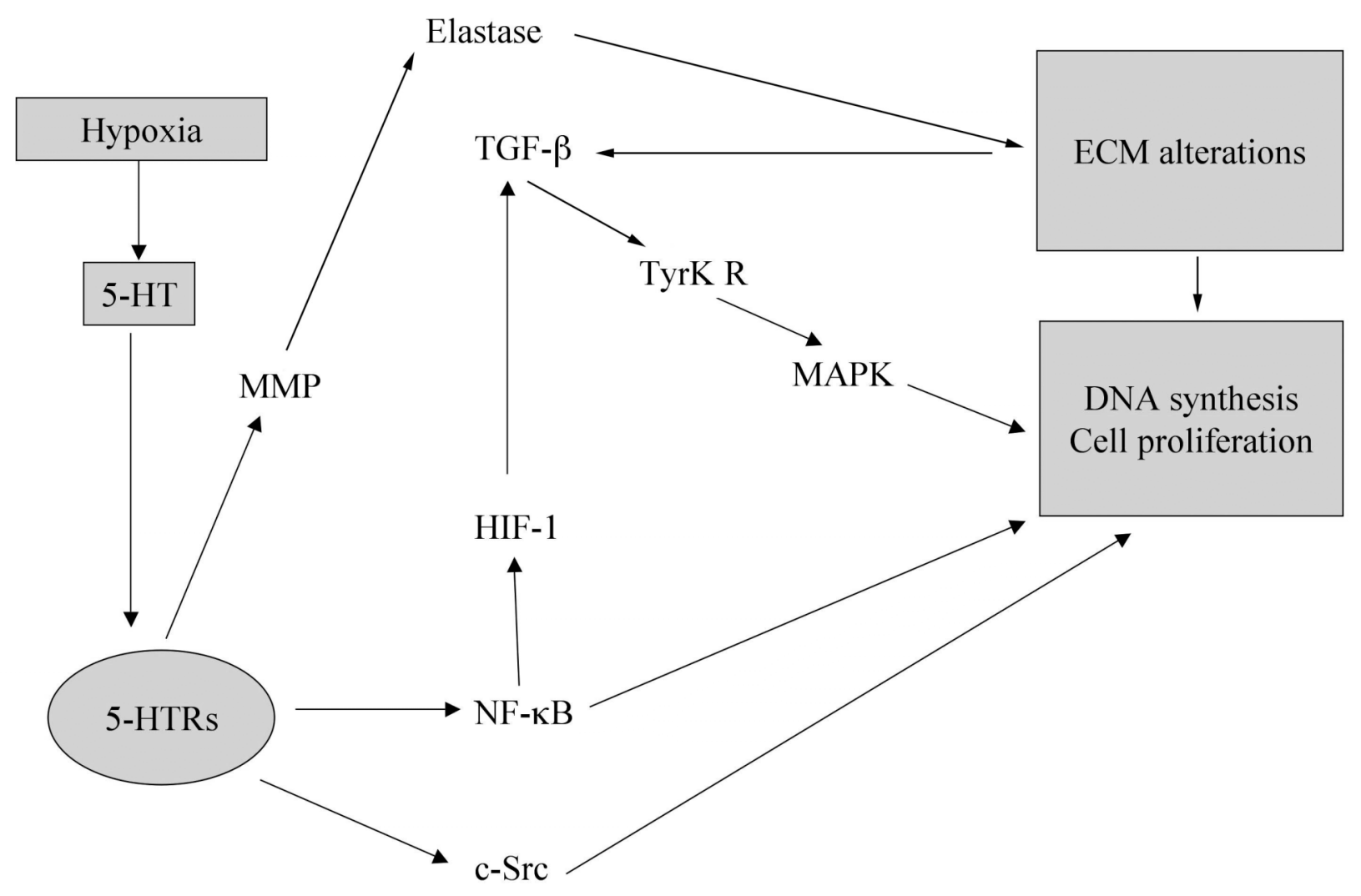

Figure 2. 5-HT-stimulated transcription pathways in the regulation of hypoxia-induced PVR.

By controlling 5-HT levels, hypoxia has effects on transcriptional and post-transcriptional control of growth factors, via proteinases, which participate in ECM maintenance, leading to PVR. 


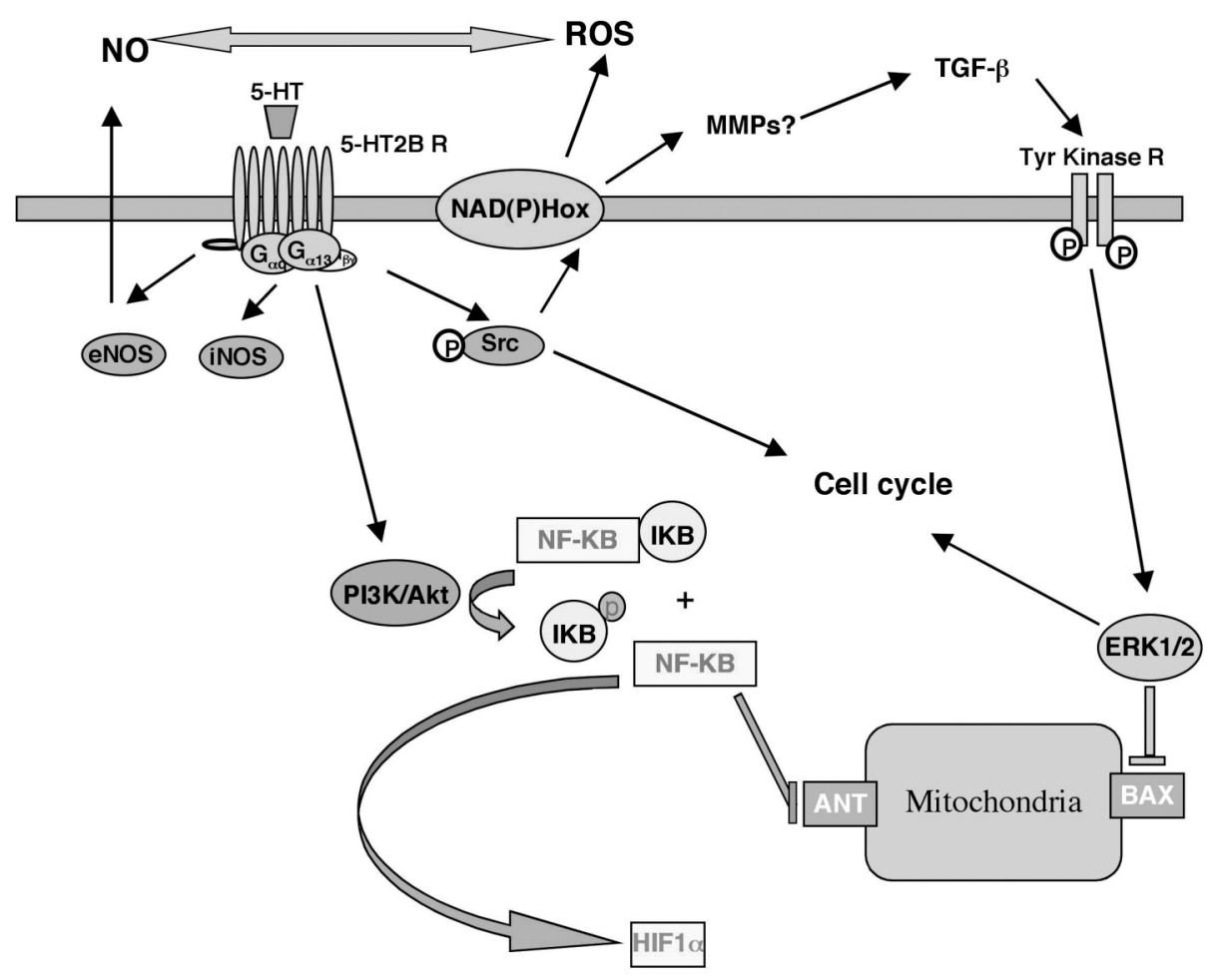

Figure 3. 5-HT ${ }_{2 \mathrm{~B}} \mathrm{R}$-induced transduction pathways relevant to pulmonary hypertension.

Different experimental evidences support a model in which ROS and NO can be controlled by 5$\mathrm{HT}_{2 \mathrm{~B}} \mathrm{R}$ that would result in transcriptional activation of cell cycle and hypoxic responses. 